Clinical Practice \& Epidemiology in
Mental Health
Content list available at: $h$ ttps://clinical-practice-and-epidemiology-in-mental-health.com

RESEARCH ARTICLE

\title{
Anxiety and Depression Among Women Living with HIV: Prevalence and Correlations
}

\author{
Abdilahi Yousuf $^{1(D)}$, Ramli Musa ${ }^{2}$, Muhammad Lokman Md. Isa ${ }^{3(D)}$ and Siti Roshaidai Mohd Arifin ${ }^{4, *(D)}$ \\ ${ }^{1}$ College of Medicine and Health Sciences, Jijiga University, Jijiga, Ethiopia \\ ${ }^{2}$ Department of Psychiatric, Kulliyah of Medicine, IIUM, Kuantan, Malaysia \\ ${ }^{3}$ Department of Basic Medical Sciences, Kulliyah of Nursing, IIUM, Kuantan, Malaysia \\ ${ }^{4}$ Department of Professional Nursing Studies, Kulliyah of Nursing, IIUM, Kuantan, Malaysia
}

\begin{abstract}
:
Introduction:

It has been found that HIV positive women are becoming increasingly affected by various illnesses, including Common Mental Disorders (CMDs) such as depression. Such comorbidity escalates the disease progression to the severe stage and commonly hinders treatment adherence. This study determined the prevalence of anxiety and depression amidst women living with HIV.

Methods:

Based on a cross-sectional and facility-based study, 357 HIV positive women were recruited using the systematic sampling technique from two public hospitals in Jijiga town, Ethiopia. The Hospital Anxiety and Depression Scale (HADS) was administered for screening, and followed by a pre-tested questionnaire that comprised of Perceived Social Support and HIV stigma.

Results:

The results revealed that the prevalence of both anxiety and depression amidst HIV positive women was $28.9 \%$ and $32.5 \%$, respectively. In the multivariate analysis, it was discovered that lack of formal education, being divorced, unemployed, and earning a monthly income less than 1400 ETB (37.5 USD) were significantly associated with depression. Women with symptomatic HIV clinical stage III (AOR $=2.06,95 \%$ C.I (0.75-5.61), with CD4 cell count below 250 (AOR $=1.14,95 \%$ C.I $(0.57-2.28)$, and with co-infections ( $\mathrm{AOR}=1.04,95 \%$ C.I $(0.40-2.71)$ also suffered from depression.

Conclusion:

The study outcomes show that the prevalence of depression in women with HIV was $32.5 \%$, but they were more likely to be depressed if they were illiterate, divorced, unemployed or had a financial burden. In addition, HIV positive women with less CD4 cell count and in the final clinical stage or suffered from a co-infection were also associated with depressive symptoms. This signifies the public health implications of psychological and cognitive morbidities of the illness among these women with chronic illnesses. Hence, future mental health interventions and HIV care should be integrated with substantial emphasis given to vulnerable groups, including HIV positive women.
\end{abstract}

Keywords: Human immune-Deficiency virus, Depression, Anxiety, Comorbidity, CD4 cell, Odds ratio.

\begin{tabular}{|l|l|l|l}
\hline Article History & Received: December 11,2019 & Revised: May 20, 2020 & Accepted: May 27, 2020
\end{tabular}

\section{INTRODUCTION}

Anxiety and depression are the two most common CMDs that plague society. Depression is characterised with altered mood, low energy, loss of pleasure, and lack of interest that may lead to poor concentration, low self-esteem, poor appetite,

\footnotetext{
* Address correspondence to this author at the Department of Professional Nursing Studies, Kulliyah of Nursing, IIUM, Kuantan, Malaysia; E-mail: roshaidai@iium.edu.my
}

guilty feelings, and disturbed sleep. On the other hand, anxiety refers to feelings of fear, distress, and panic disorder that cause phobias and stress. Some anxiety disorders are obsessivecompulsive disorders, generalised and social anxiety disorders, as well as post-traumatic stress disorders. Such mental disorders are a global public health burden, as more than 300 million and 264 million people worldwide are affected by depression and anxiety, respectively [1]. These CMDs are ranked third in contributing to disabilities and infirmities. 
Depression alone is estimated to represent about $15 \%$ of the total global disease burden in 2020 [2].

The recurrence rates of anxiety and depression are two to four-fold amongst HIV positive patients than the rest of the population [3]. These two CMDs, which are a long-standing challenge in the public health sector, are usually unnoticed and remain a potentially risky condition that can affect not only the social aspect of their quality of life, social interactions, and adherence to treatment $[4-6]$, but also their life expectancy [7].

Besides, HIV positive patients with comorbid diseases, such as depression or anxiety, are more likely to acquire viral resistance, and as a consequence, develop poor health outcomes due to low treatment adherence, especially decreased CD4 level [8 - 12]. Advanced and fatal trajectory has been reported when depression and anxiety occur as comorbid diagnosed in a chronic patient [13].

This may result in substantial public health risk, which raises the need for further studies and effective prevention strategies so as to ascertain better health outcomes and improved quality of life for patients in Sub-Saharan Africa diagnosed with HIV.

The burden of this comorbidity shows the high prevalence of these CMDs among HIV patients than the general population [14]. The magnitude of the problem is amplified when HIV is widespread among those with high vulnerability, stigmatised, and marginalised, such as women, racial or ethnic minority, people with disabilities, or those with a higher level of depression than the rest [15].

So far, depression is highly prevalent in Ethiopia, and it is considered as one of the common psychiatric disorders that affect women as its associates are gender-specific. Some studies conducted in Ethiopia revealed a high prevalence of depression amidst AIDS/HIV patients, whereby $38.94 \%$ of the studied participants were depressed [16].

Women diagnosed with HIV have been substantially investigated to address worldwide HIV transmission issues within the biomedical domain. Nevertheless, studies regarding the psychosocial well-being of HIV positive women across developing and developed nations are in scarcity [17].

In developing countries, depression is a serious barrier that must be addressed when discussing HIV prevention as the two diseases are fundamentally linked and aggravate each other. Some studies reported that depressive symptoms and depression reflect the poor adherence to HIV treatment, thus adversely affecting the desired clinical results [18].

Despite the long-reckoned importance of screening depression and managing HIV positive patients across healthcare facilities, their prevalence and risk factors on women have remained untapped. As such, this study exhaustively assessed the prevalence and correlations of anxiety and depression amongst HIV positive women.

\section{METHODS}

This study involved two hospitals based on their comprehensive service provision. In accordance with the national HCT guideline, secondary- and tertiary-level healthcare facilities offer minimum curative and preventive packages. Hence, healthcare facilities were purposively selected for their key service delivery and availability of chronic patients. As such, a cross-sectional study was conducted in antiretroviral treatment clinics of two hospitals located in Jijiga town of eastern Ethiopia in June 2019. The study population comprised of women aged 18 years and above attending HIV treatment service at the two selected hospitals. To estimate the required sample size, a single population proportion formula had been applied. The prevalence of depression (P) from a baseline study in Ethiopia was 38.9\% with $5 \%$ significant level, $Q=0.05, / 2=1.96$, and $5.0 \%$ absolute precision or margin of error tolerance $(d=0.05)$. The Epi Info software suggested 357 women as the study sample size. The systematic sampling method was applied to select the participants for this study. To determine the sampling interval, those with appointments during the data collection period were divided by the total sample size, wherein the initial point was selected in a random manner.

A trained nurse conducted the interview with women attending the antiretroviral treatment centres using a pretested structured questionnaire. Apart from the socio-demographic profile, their clinical and laboratory investigation results were retrieved as well. Women participants were screened with the HADS tool. This tool is composed of seven questions each for anxiety and depression. Although these 14 questions are interspersed in the questionnaire, they must be scored in a separate manner. A score of 8-10 signifies mild depression, while 11-14 is moderate, and 15-21 indicates severe depression. Besides, the PSS-HIV scale was used to assess the level of perceived support in women with HIV. This 12-item scale has examined women's self-esteem, self-development and belongingness. Moreover, the HIV stigma scale was used to measure the extent of stigma by examining the negative selfimage, concerns about public attitude, disclosure concerns and personalized stigma.

The gathered data were analysed using IBM SPSS statistics version 22. Multivariable logistic regression was performed by using forward stepwise logistic regression to identify the independent variables linked with the outcome variable. Variables with p-value 0.005 or less were incorporated into the model. Odds Ratio (OR) and Adjusted Odds Ratio (AOR), along with their Confidence Interval $(95 \% \mathrm{CI})$, were calculated to identify the strength of the correlations.

Ethical approval of the study was obtained from the International Islamic University of Malaysia Research Ethics Committee (IREC). A permission letter was also obtained from the University's board of review. Written informed consent was collected from the participants after explaining the study aims and other information relevant to this study. The confidentiality and privacy of the participants had been strictly maintained.

\section{RESULTS}

\subsection{Socio-demographic Characteristics}

In total, 357 participants were involved in this study and the mean value of their age was 34.2 years ( $\mathrm{SD}=8.8$ years). 
Table 1. Socio-demographic characteristics of women living with HIV attending hospitals, 2019 (n= 357).

\begin{tabular}{|c|c|c|c|}
\hline Variable & Categories & Frequency & Percent (\%) \\
\hline Residence & Urban & 332 & 93.0 \\
\hline- & Rural & 25 & 7.0 \\
\hline Age & $18-24$ & 54 & 15.1 \\
\hline- & $25-49$ & 290 & 81.2 \\
\hline- & $>50$ & 13 & 3.6 \\
\hline Marital Status & Married & 134 & 37.5 \\
\hline- & Single & 100 & 28.0 \\
\hline- & Widowed & 77 & 21.6 \\
\hline- & Divorced & 46 & 12.9 \\
\hline No of living children & Nulliparous/No children & 173 & 48.5 \\
\hline- & $1-3$ & 142 & 39.8 \\
\hline- & $4-6$ & 42 & 11.8 \\
\hline Education & No formal education & 166 & 46.5 \\
\hline- & Formal education & 191 & 53.5 \\
\hline Ethnicity & Amhara & 130 & 36.4 \\
\hline- & Somali & 113 & 31.7 \\
\hline- & Oromo & 65 & 18.2 \\
\hline- & Southern Nations & 31 & 8.7 \\
\hline- & Others & 18 & 5 \\
\hline Faith & Islam & 165 & 46.2 \\
\hline- & Orthodox & 151 & 42.3 \\
\hline- & Catholic & 12 & 3.4 \\
\hline- & Protestant & 29 & 8.1 \\
\hline Occupation & Unemployed & 129 & 36.1 \\
\hline- & Student & 89 & 24.9 \\
\hline- & Self-employed & 55 & 15.4 \\
\hline- & Government employee & 84 & 23.5 \\
\hline Income in ETB & $<1400$ & 173 & 48.5 \\
\hline- & $1400-3800$ & 80 & 22.4 \\
\hline- & $>3800$ & 104 & 29.1 \\
\hline
\end{tabular}

Most of the participants were urban dwellers ( $n=332,93 \%)$ and derived from the Amhara ethnicity ( $\mathrm{n}=130,36.4 \%)$. Among the total participants, 134 (37.5\%) were married, and $165(46.2 \%)$ belonged to Islam. Around half of the participants $(46.2 \%)$ did not attend any formal education, while 129 (36.1\%) were unemployed, and $173(48.5 \%)$ reported that their family earned less than 1400 Ethiopian Birr or 37.5 US dollars based on the Ethiopian poverty assessment. Besides, most of them were nulliparous $173(48.5 \%)$. Table 1 tabulates the demographic profile of the participants.

\subsection{Clinical Characteristics of the Study Participants}

The clinical characteristics of the participants were assessed, including clinical staging level, viral load and CD4 level, as well as the comorbidity of the common opportunistic infections.

Out of the 357 participants interviewed, 127 (35.6\%) of them were in WHO clinical stage I, and followed by 93 (26.1\%) at clinical stage III. As for virological examination, $151(42.3 \%)$ of the participants had a CD4 count above 475 cell/1, and followed by $111(31.1 \%)$ with a CD4 count ranging from 251-475 cell/1. A total of 175 respondents (49.0) complained suffering from at least a common opportunistic infection.

\subsection{Depression and Anxiety Prevalence}

The HADS was used to screen the study participants. The prevalence of depression and anxiety of the participants was $32.5 \%$ and $28.9 \%$, respectively, while comorbid prevalence was $22.7 \%$. The scores of anxiety and depression revealed that $18.2 \%$ of the participants had symptoms of severe depression, $12.0 \%$ experienced moderate depression, and $1.7 \%$ suffered from mild depression.

In HADS, a higher rating denotes a higher level of anxiety and depression. For the scales of anxiety and depression, scores under 7 suggest that the participants were not depressed, scores 8-10 reflect mild cases, 11-14 are moderate, and 15-21 display severe cases.

\subsection{Factors of Depression and Anxiety Among HIV Positive Women}

Binary logistic regression was employed in this study to identify the correlations of socio-demographic profiles, as well as clinical and virologic factors, with anxiety and depression. 
In order to control the influence of a potential third variable, and to avoid non-causal association due to this confounding factor, a step-wise logistic regression was carried out, and the adjusted multivariable was assessed by including factors that were significant in the binary regression analysis.

The outcomes revealed that marital status, education level, occupation, and monthly income of the participants were significantly related to both anxiety and depression. Other socio-demographic variables, such as the age of the participants, residence, ethnicity, faith, and the number of living children, had no association with anxiety and depression.

The clinical characteristics of the participants, such as HIV clinical staging, number of CD4 cell counts, and presence of opportunistic infections, were significantly linked with depression and anxiety, as presented in Tables $\mathbf{2}$ and $\mathbf{3}$, respectively.

In multivariate analysis, the results revealed that divorced women were twice more likely to develop anxiety (AOR = $2.83,95 \% \mathrm{CI}(0.80-10.1)$ and four times more likely to acquire depression $(\mathrm{AOR}=4.18,95 \% \mathrm{CI}(1.26-13.8)$. Women without formal education exhibited more prevalence in anxiety $(\mathrm{AOR}=$ $1.71,95 \% \mathrm{CI}(0.64-4.57)$ and depression $(\mathrm{AOR}=1.45,95 \% \mathrm{CI}$ (0.55-3.82) than those with academic background.

The findings displayed a higher prevalence of anxiety $(\mathrm{AOR}=4.09$, CI $(1.56-10.8)$ and depression $(\mathrm{AOR}=2.17$, $95 \% \mathrm{CI}(0.85-5.56)$ among unemployed women and they were significantly more prevalent among those who earned less than 1400 ETB a month.

Women with symptomatic HIV clinical stage IV (AOR $=3.61,95 \%$ CI $(1.07-12.2)$ for anxiety and clinical stage III $(\mathrm{AOR}=2.06,95 \% \mathrm{CI}(0.75-5.61)$ for depression, those with CD4 cell count below $250(\mathrm{AOR}=1.62,95 \% \mathrm{CI}(0.79-3.32)$ for anxiety and $(\mathrm{AOR}=1.14,95 \% \mathrm{CI}(0.57-2.28)$ for depression, as well as those with an opportunistic infection, were more likely to suffer from anxiety and depression.

Spearman's coefficient test was used to determine the correlation among perceived social support, HIV stigma, and depression.

Table 2. Multiple regression analysis between anxiety and associated factors among participants attending hospitals, 2019.

\begin{tabular}{|c|c|c|c|c|}
\hline \multirow{2}{*}{$\begin{array}{c}\text { Descriptive } \\
\text { Anxiety cases } \\
\text { n (\%) }\end{array}$} & \multicolumn{2}{|c|}{ HADS-A } & \multirow[b]{2}{*}{ Odds Ratio $[95 \% \mathrm{CI}]$} & \multirow[b]{2}{*}{ Adjusted Odds Ratio (95\% CI) } \\
\hline & $\begin{array}{c}\text { None Anxiety cases } \\
\text { n (\%) }\end{array}$ & & & \\
\hline Marital Status & - & - & - & - \\
\hline Married & $52(38.8)$ & $82(61.2)$ & 1 & 1 \\
\hline Single & $23(23)$ & $77(77)$ & $2.12[1.19-3.79]$ & $1.82[0.56-5.86]$ \\
\hline Widowed & $19(24.7)$ & $58(75.3)$ & $1.94[1.04-3.61]$ & $1.59[0.57-4.44]$ \\
\hline Divorced & $9(19.6)$ & $37(80.4)$ & $2.61[1.16-5.84]$ & $2.83[0.80-10.1]$ \\
\hline Education & - & - & - & - \\
\hline Formal education & $67(35.1)$ & $124(64.9)$ & 1 & 1 \\
\hline No formal education & $36(21.7)$ & $130(78.3)$ & $1.95[1.22-3.14]$ & $1.71[0.64-4.57]$ \\
\hline Occupation & - & - & - & - \\
\hline Unemployed & $28(21.7)$ & $101(78.3)$ & $2.04[1.09-3.80]$ & $4.09[1.56-10.8]$ \\
\hline Student & $28(31.5)$ & $61(68.5)$ & $0.79[0.41-1.55]$ & $2.15[0.93-4.93]$ \\
\hline Self-employed & $12(21.8)$ & $43(78.2)$ & $1.02[0.48-2.17]$ & $3.44[1.36-8.73]$ \\
\hline Govt employee & $35(41.7)$ & $49(58.3)$ & 1 & 1 \\
\hline Income & - & - & - & - \\
\hline$<1400$ & $37(21.5)$ & $135(78.5)$ & $1.62[0.93-2.82]$ & $0.97[0.43-2.18]$ \\
\hline $1400-3800$ & $34(42)$ & $47(58)$ & $0.61[0.34-1.13]$ & $0.54[0.26-1.13]$ \\
\hline$>3800$ & $32(30.8)$ & $72(69.2)$ & 1 & 1 \\
\hline Clinical staging & - & - & - & - \\
\hline Stage I & $49(38.9)$ & $77(61.1)$ & 1 & 1 \\
\hline Stage II & $23(28.1)$ & $59(71.9)$ & $1.63[0.89-2.98]$ & $1.25[0.38-4.11]$ \\
\hline Stage III & $21(22.6)$ & $72(77.4)$ & $2.18[1.19-3.99]$ & 1.59 [0.56-4.55] \\
\hline Stage IV & $10(5.6)$ & $46(94.4)$ & $2.93[1.35-6.34]$ & $3.61[1.07-12.2]$ \\
\hline CD4 count & - & - & - & - \\
\hline$<250$ & $18(18.9)$ & $77(81.1)$ & $1.66[0.89-3.11]$ & $1.62[0.79-3.32]$ \\
\hline $251-475$ & 42 (37.8). & $69(62.2)$ & $0.62[0.37-1.05]$ & $0.92[0.49-1.69]$ \\
\hline$>475$ & $43(28.5)$ & $108(71.5)$ & 1 & 1 \\
\hline OI comorbidity & - & - & - & - \\
\hline Yes & $41(23.4)$ & $134(76.6)$ & $1.69[1.06-2.69]$ & $1.03[0.39-2.70]$ \\
\hline No & $62(34.1)$ & $120(65.9)$ & 1 & 1 \\
\hline
\end{tabular}


Table 3. Multiple regression between depression and factors associated with participants attending hospitals, 2019.

\begin{tabular}{|c|c|c|c|c|}
\hline \multirow{2}{*}{$\begin{array}{c}\text { Descriptive } \\
-\end{array}$} & \multicolumn{2}{|c|}{ HADS-D } & \multirow[b]{2}{*}{ Odds Ratio $[95 \%$ CI $]$} & \multirow[b]{2}{*}{ Adjusted Odds Ratio (95\% CI) } \\
\hline & Depressed n (\%) & $\begin{array}{c}\text { Not Depressed } \\
\text { n (\%) }\end{array}$ & & \\
\hline Marital Status & - & \begin{tabular}{|l|}
- \\
\end{tabular} & - & - \\
\hline Married & $57(42.5)$ & $77(57.5)$ & 1 & 1 \\
\hline Single & $25(25)$ & $75(75)$ & $2.12[1.19-4.25]$ & $2.08[0.66-6.56]$ \\
\hline Separated & $23(29.9)$ & $54(70.1)$ & $1.44[0.88-3.02]$ & $1.54[0.59-4.08]$ \\
\hline Divorced & $11(23.9)$ & $35((76.1)$ & $2.35[1.15-4.78]$ & $4.18[1.26-13.8]$ \\
\hline Education & - & - & - & - \\
\hline Formal education & $68(39.5)$ & $104(60.5)$ & 1 & 1 \\
\hline No formal education & $48(25.9)$ & $137(74.1)$ & $1.77[1.22-2.79]$ & $1.45[0.55-3.82]$ \\
\hline Occupation & - & - & - & - \\
\hline Unemployed & $31(24)$ & $98(76)$ & $2.26[1.25-4.08]$ & $2.17[0.85-5.56]$ \\
\hline Student & $32(36)$ & $57(64)$ & $1.27[0.69-2.35]$ & $1.09[0.49-2.44]$ \\
\hline Self-employed & $18(32.7)$ & $37(67.3)$ & $1.47[0.72-2.99]$ & $1.19[0.50-2.84]$ \\
\hline Govt employee & $35(41.7)$ & $49(58.3)$ & 1 & 1 \\
\hline Income & - & - & - & - \\
\hline$<1400$ & $40(23.3)$ & $132(76.7)$ & $1.56[0.91-2.68]$ & $1.24[0.56-2.74]$ \\
\hline $1400-3800$ & $42(51.9)$ & $39(48.1)$ & $0.46[0.25-0.84]$ & $0.49[0.24-0.98]$ \\
\hline$>3800$ & $34(32.7)$ & $70(67.3)$ & 1 & 1 \\
\hline Clinical staging & - & - & - & - \\
\hline Stage I & $54(42.5)$ & $73(57.5)$ & 1 & 1 \\
\hline Stage II & $24(29.6)$ & $57(70.4)$ & $1.76[0.97-3.18]$ & $1.28[0.40-4.08]$ \\
\hline Stage III & $23(24.7)$ & $70(75.3)$ & $2.25[1.25-4.05]$ & $2.06[0.75-5.61]$ \\
\hline Stage IV & $15(26.8)$ & $41(73.2)$ & $2.02[1.02-4.02]$ & $1.36[0.45-4.13]$ \\
\hline CD4 count & - & - & - & - \\
\hline$\leq 250$ & $20(21.1)$ & $75(78.9)$ & $1.49[0.82-2.74]$ & $1.14[0.57-2.28]$ \\
\hline $251-475$ & $53(47.7)$ & $58(52.3)$ & $0.44[0.26-0.73]$ & $0.50[0.28-0.92]$ \\
\hline$>475$ & $43(28.5)$ & $108(71.5)$ & 1 & 1 \\
\hline OI comorbidity & - & - & - & - \\
\hline Yes & $48(27.4)$ & $127(72.6)$ & $1.58[1.01-2.47]$ & $1.04[0.40-2.71]$ \\
\hline No & $68(37.4)$ & $114(62.6)$ & 1 & 1 \\
\hline
\end{tabular}

A significantly negative correlation was found between perceived social support and depression $(r=r=-0.11 \mathrm{p}=$ 0.037 ) with $\mathrm{BCa} 95 \%$ confidence interval $[-0.21$ to -0.02$]$ and anxiety $(r=-0.15 \mathrm{p}=0.005)$ with $\mathrm{BCa} 95 \%$ confidence interval $[-0.26$ to -0.04$]$ among the participants.

The lower score of perceived social support among the participants suggested a higher level of anxiety and depression.

Meanwhile, a positive correlation was found between HIV stigma, and depression $(r=0.37 \mathrm{p}<0.001)$ with $\mathrm{BCa} 95 \%$ confidence interval $[0.26$ to 0.46$]$ and anxiety $(r=0.36 \mathrm{p}<0.01)$ with $\mathrm{BCa} 95 \%$ confidence interval [0.24 to 0.46$]$.

This showed that higher scores of HIV stigma among the study participants denoted a higher level of anxiety and depression, as tabulated in Table $\mathbf{3}$.

\section{DISCUSSION}

This study had assessed the prevalence and correlations of depression and anxiety among HIV positive women from two selected hospitals in eastern Ethiopia. The work is part of an extended mixed-method study with an emphasis on women living with HIV. This study verifies the results of past research work that reported a higher prevalence in women than men [19 - 23]. In this study, the symptoms of depression were measured using the HADS screening tool. The other scales used in this study were the PSS-HIV scale to assess social support and HIV stigma. As a result, the prevalence rate of depression among the participants was $32.5 \%$. This is lower when compared to other studies from Sub-Saharan Africa, such as $48 \%$ in Kenya [24] and $48.7 \%$ in South Africa [25]. This is ascribed to the difference in the study population recruited in these studies, which comprised of women in postpartum/pregnancy with a period of high susceptibility to depression. However, the prevalence of this study is higher when compared to other studies also conducted in developing countries, such as $11 \%$ in Malawi [21].

A number of reasons can be attributed to the prevalence of depression in these countries. Firstly, there is a difference in the screening tools used. For instance, studies in Malawi [21], Kenya [24], and South Africa [25] used the EPDS screening tool, whereas a study in Uganda applied the CES-D for screening. The other reasons refer to the methodological variations and the sample size difference. 
The comorbid prevalence of anxiety and depression was 22.5\%. According to Dell'Osso and Pini [26], the possible clarifications for these comorbid mental illnesses might be that both disorders are likely to share the same phenomena or common symptoms or vulnerabilities. Upon close examination, the findings revealed that the point prevalence of these comorbid illnesses is marginally higher than the institutionalbased cross-sectional study conducted on pregnant women in Tanzania (18.1\%) [27].

A number of factors have been identified related to the development of anxiety and depression among women living with HIV. For instance, in this study, divorcees were found to be more likely to develop both depression and anxiety. Similar findings have been reported in studies conducted in Ethiopia [28] and Uganda [29], thus revealing that women who were not living with their partner or divorced were at higher risk of acquiring depression. A study conducted in Ukraine by Bailey [30] discovered that non-cohabiting and single mothers were more likely to be depressed. This justifies that broken-up families or insecure marital engagements intensify the risk of developing depressive symptoms. This is commonly observed among abandoned partner, who usually suffers from psychological and emotional disturbances when they miss their loved one(s) or when feeling the burden of family-related workload alone with no or less support.

It was revealed that women who were illiterate, unemployed, and whose monthly household income was less than 1400 Ethiopian Birr were at higher risk for anxiety and depression. The results are consistent with those reported in a study that involved South African HIV positive women, which presented that low-income and unemployment were related to depression $[25,31]$. The reason could be that in low-income countries, women are pressured to default academics for poverty-related factors, which later result in their more prominent engagement on domestic work, as well as the lack of access to health education and awareness. This is ascribed to the possible negative interaction between mental disorders (e.g., depression) and poverty, primarily because, in principle, people with depression commonly perform poorly in their daily tasks [32]. Moreover, a number of studies carried out in highincome countries revealed that people with social and economic disadvantages are more likely to develop depression [33], indicating the substantial relationships between social adversity, HIV, and depression. Based on the world federation on mental health, women tend to suffer from depression twofold more than men due to financial issues, lack of formal education, and potential exposure to violence [34].

This study found that women with symptomatic HIV clinical stage IV for anxiety and clinical stage III for depression, CD4 cell count below 250 cells $/ \mathrm{mm}$, and opportunistic infection were more likely to suffer from anxiety and depression. Similarly, other studies conducted in the Russian Federation [35], the USA [36], China [9], and Ethiopia [37] reported that a decrease in $\mathrm{Cd} 4$ cell counts and an increase in viral load were significantly related to both depression and anxiety. This is attributed to the effect of depression on HIV disease progression by suppressing the immune system, and this immunosuppression, may, in turn, be a predictor for the development of depression among HIV patients [10, 38]. Additionally, the growing evidence suggests the significant role of immunological factors, such as CD4 cells, on the pathophysiology of depression development, particularly among patients with chronic illnesses.

Regarding women's expected support, a significantly negative correlation was reported between perceived social support and depression. Similarly, a study on HIV positive Malawian women indicated that depressive symptoms were associated with decreased perceived social support [39]. In line with this, numerous studies conducted in Sub-Saharan Africa have reported the significant relationship between depressive symptoms and social support [40]. This manifests that social support represents the scope of one's level of satisfaction in relation to the necessity of support, information, and interaction, apart from being a key element for coping with depression. Brittain et al. [41] asserted that the substantial moderator between social support and depression was the stigma perceived by women with HIV.

\section{CONCLUSION}

This study found a positive correlation between HIV stigma and depression, which is consistent with previous findings (Benoit et al., 2014; Gonzalez et al., 2012; Logie et al., 2013). Apprehension and depression are attributable to one's expected fear of social acceptance. This emotional disturbance may be related to feelings of not receiving the deserved public attention due to their illness or their depressive circumstances.

Hence, as this study is a cross-sectional one, the possible limitation is the lack of possibility to examine the causal association between social support and stigma with the dependent variable; depression. The other possible limitation is, the interview was not carried out by a psychiatrist who could sub-standardize the quality of the data collection. However, the findings suggest the need for further longitudinal studies in the future by taking into account several potential risk factors.

In conclusion, this study reveals that depression and anxiety are indeed prevalent among women living with HIV. These gender-specific mental health gaps need to be addressed in order to develop effective strategies that enhance the integration of mental health in the HIV care setup.

\section{LIST OF ABBREVIATIONS}

$\begin{array}{ll}\text { AIDS } & =\text { Acquired Immune Deficiency Syndrome } \\ \text { ART } & =\text { Antiretroviral Therapy } \\ \text { AOR } & =\text { Attributed Odds Ratio } \\ \text { CD4 } & =\text { Cluster of Deferentiation-4 } \\ \text { CMD } & =\text { Common Mental Disorders } \\ \text { COR } & =\text { Crude Odds Ration } \\ \text { HADS } & =\text { Hospital Anxiety and Depression Scale } \\ \text { HIV } & =\text { Human Immunodeficiency Virus } \\ \text { OI } & =\text { Opportunistic Infection } \\ \text { WLHIV } & =\text { Women Living with HIV }\end{array}$




\section{ETHICS APPROVAL AND CONSENT TO PARTI- CIPATE}

Ethical approval of this study was obtained from the International Islamic University of Malaysia Research Ethics Committee (IREC). A permission letter was also obtained from the Jijiga University board of review.

\section{HUMAN AND ANIMAL RIGHTS}

Not applicable.

\section{CONSENT FOR PUBLICATION}

Written informed consent was attained from each study participant after clarifying the purpose of the study. The privacy and confidentiality of the participants had been strictly maintained.

\section{AVAILABILITY OF DATA AND MATERIALS}

The data that support the findings of this research are available from the corresponding author [G.T] upon request.

\section{FUNDING}

This study did not receive any funding from the public or private sectors.

\section{CONFLICT OF INTEREST}

The authors declare no conflict of interest, financial or otherwise.

\section{ACKNOWLEDGEMENTS}

Declared none.

\section{REFERENCES}

[1] World Health Organization. Depression and other common mental disorders. 2017.

[2] Murray C, Lopez AE. Global burden of disease: A comprehensive assessment of mortality and disability from diseases, injuries, and risk factors in 1990 and projected to 2020 (Global Burden of Disease and Injury Series). Cambridge: MA Harvard Sch Public Heal 2019.

[3] Bernard C, Dabis F, de Rekeneire N. Prevalence and factors associated with depression in people living with HIV in sub-Saharan Africa: A systematic review and meta-analysis. PLoS One 2017; 12(8)e 0181960 [http://dx.doi.org/10.1371/journal.pone.0181960] [PMID: 28783739.]

[4] Dejesus RS, Angstman KB, Cha SS, Williams MD. Antidepressant medication use among patients with depression: com- parison between usual care and collaborative care using care managers. Clin Pract Epidemiol Ment Health 2008; 2013: 84-7.

[5] Bitew T, Hanlon C, Kebede E, Medhin G, Fekadu A. Antenatal depressive symptoms and maternal health care utilisation: a population-based study of pregnant women in Ethiopia. BMC Pregnancy Childbirth 2016; 16(1): 301.

[http://dx.doi.org/10.1186/s12884-016-1099-1] [PMID: 27724876]

[6] Meffert SM, Neylan TC, McCulloch CE, et al. East African HIV care: depression and HIV outcomes. Glob Ment Heal 2019.

[7] Rabkin JG. HIV and depression: 2008 review and update. Curr HIV/AIDS Rep 2008; 5(4): 163-71.

[http://dx.doi.org/10.1007/s11904-008-0025-1] [PMID: 18838056]

[8] Kee MK, Lee SY, Kim NY, et al. Anxiety and depressive symptoms among patients infected with human immunodeficiency virus in South Korea. AIDS Care 2015; 27(9): 1174-82.

[http://dx.doi.org/10.1080/09540121.2015.1035861] [PMID: 26197063]

[9] Wang YY, Zhao J, Zhang Q, et al. Prevalence of depressive syndrome and their association with demographic and clinical characteristics in Chinese HIV patients. AIDS Care 2018; 30(11): 1388-92. [http://dx.doi.org/10.1080/09540121.2018.1465172]

[PMID: 29690783]

[10] Prasithsirikul W, Chongthawonsatid S, Ohata PJ, et al. Depression and anxiety were low amongst virally suppressed, long-term treated HIVinfected individuals enrolled in a public sector antiretroviral program in Thailand. AIDS Care 2016. [PMID: 27683949]

[11] Owora AH. Major depression disorder trajectories and HIV disease progression: results from a 6-year outpatient clinic cohort. Medicine (Baltimore) 2018; 97(12)e0252

[http://dx.doi.org/10.1097/MD.0000000000010252]

[PMID: 29561455]

[12] Ironson G, O'Cleirigh C, Kumar M, et al. Psychosocial and neurohormonal predictors of HIV disease progression (CD4 cells and viral load): A 4 year prospective study. AIDS Behav 2015; 19(8): 1388-97.

[http://dx.doi.org/10.1007/s10461-014-0877-x] [PMID: 25234251]

[13] Stewart BJR, Turnbull D, Mikocka-walus AA, Harley H, Andrews JM. An aggravated trajectory of depression and anxiety co-morbid with hepatitis c: A within-groups study of 61 australian outpatients. Clin Pract Epidemiol Ment Heal 2015; pp. 174-9.

[14] Lundberg P, Nakasujja N, Musisi S, Thorson AE, Cantor-Graae E, Allebeck P. HIV prevalence in persons with severe mental illness in Uganda: a cross-sectional hospital-based study. Int J Ment Health Syst 2013

20.http://ijmhs.biomedcentral.com/articles/10.1186/1752-4458-7-20 [http://dx.doi.org/10.1186/1752-4458-7-20] [PMID: 23866085]

[15] Fasoulakis Z. The social stigma of HIV - AIDS: society's role. HIV/AIDS - Res. Palliat Care 2017; $f$ ? $f$ ? $>f ?>$ : 111-8.

[16] Eshetu DA, Meseret SW, Kebede MA, et al. Prevalence of depression and associated factors among hiv / aids patients attending art clinic at debrebirhan referral hospital, north showa, amhara region, ethiopia. Ann Clin Psychiatry 2015; 1(1): 3.

[17] Sikkema KJ, Dennis AC, Watt MH, Choi KW, Yemeke TT, Joska JA. Improving mental health among people living with HIV: a review of intervention trials in low- and middle-income countries. Glob Ment Heal [Internet] 2015; 2e19 Available from: http://www.journals.cambridge.org/abstract_S2054425115000175

[18] Bouhnik AD, PrA(c)au M, Vincent E, et al. MANIF 2000 Study Group. Depression and clinical progression in HIV-infected drug users treated with highly active antiretroviral therapy. Antivir Ther (Lond) 2005; 10(1): 53-61.

[PMID: 15751763]

[19] Natamba BK, Achan J, Arbach A, et al. Reliability and validity of the center for epidemiologic studies-depression scale in screening for depression among HIV-infected and -uninfected pregnant women attending antenatal services in northern Uganda: a cross-sectional study. BMC Psychiatry 2014; 14(303): 303.

[http://dx.doi.org/10.1186/s12888-014-0303-y] [PMID: 25416286]

[20] Hatcher AM, Tsai AC, Kumbakumba E, et al. Sexual relationship power and depression among HIV-infected women in Rural Uganda. PLoS One 2012; 7(12)e49821

[http://dx.doi.org/10.1371/journal.pone.0049821] [PMID: 23300519]

[21] Anna Dow, Queen Dube, Brian W. Pence and AVR. Postpartum depression and hiv infection among women in malawi. J Acquir Immune Defic Syndr 2015; 65(3): 359-65. [PMID: 25469525]

[22] Turan B, Stringer KL, Onono M, et al. Linkage to HIV care, postpartum depression, and HIV-related stigma in newly diagnosed pregnant women living with HIV in Kenya: a longitudinal observational study. BMC Pregnancy Childbirth 2014; 14: 400. [http://dx.doi.org/10.1186/s12884-014-0400-4] [PMID: 25467187]

[23] Onu C, Ongeri L, Bukusi E, et al. Interpersonal psychotherapy for depression and posttraumatic stress disorder among HIV-positive women in Kisumu, Kenya: study protocol for a randomized controlled trial. BMC Trials [Internet] 2016; 1-8 Available from: [http://dx.doi.org/10.1186/s13063-016-1187-6]

[24] Yator O, Mathai M, Vander Stoep A, Rao D, Kumar M. Risk factors for postpartum depression in women living with HIV attending prevention of mother-to-child transmission clinic at Kenyatta National Hospital, Nairobi. AIDS Care 2016; 28(7): 884-9.

[http://dx.doi.org/10.1080/09540121.2016.1160026] 27045273]

[25] Peltzer K, Rodriguez VJ, Jones D. Prevalence of prenatal depression and associated factors among HIV-positive women in primary care in Mpumalanga province, South Africa. J Soc Asp HIV/AIDS 2016; 13(1): 60-7. 
[26] Osso LD, Pini S. What Did We Learn from Research on Comorbidity.Psychiatry. Advantages and Limitations in the Forthcoming DSM-V Era. Clin Pract Epidemiol Ment Heal 2012; pp. $180-4$.

[27] Ngocho JS, Watt MH, Minja L, et al. Depression and anxiety among pregnant women living with HIV in Kilimanjaro region, Tanzania. PLoS One 2019; 14(10)e0224515

[http://dx.doi.org/10.1371/journal.pone.0224515] [PMID: 31671160]

[28] Fantahun A, Cherie A, Deribe L. Clin Pract Epidemiol Ment Health 2016; 2018: 196-206

[29] Kakyo TA, Muliiraj JK, Kizza IB, et al. Factors associated with depressive symptoms among postpartum mothers inarural district in Uganda. Sci J Midwifery 2012; p. 29.

[30] Bailey H, Malyuta R, Semenenko I, Townsend CL, Cortina-Borja M, Thorne C. Ukraine European Collaborative Study in EuroCoord. Prevalence of depressive symptoms in pregnant and postnatal HIVpositive women in Ukraine: a cross-sectional survey. Reprod Health 2016; 13(27): 27.

[http://dx.doi.org/10.1186/s12978-016-0150-z] [PMID: 27000405]

[31] Tolla T. Black Women's Experiences of Domestic Work: Domestic Workers in Mpumalanga. University of Cape Town uct.ac.za/sites/default/files/image_tool/images/117/TsidisoTolla_.pdf2 013.

[32] Al Jarad A, Al Hadi A, Al Garatli A, Akram A, Alsaeidi D, Al F, et al. Impact of Cognitive Dysfunction in the Middle East Depressed Patients: The ICMED Study. Clin Pract Epidemiol Ment Heal 2018; pp. $270-83$.

[33] Vu H, Shaya FT. Predicting factors of depression, antidepressant use and positive response to antidepressants in perinatal and postpartum women abstract. Clin Pract Epidemiol Ment Heal 2017; (410): 49-60.

[34] World Federation For Mental Health (WFMH). Depression: A Global Crisis. World Ment Heal Day [Internet] 2012; 32 Available from: http://www.who.int/mental_health/management/depression/wfmh_pap er depression wmhd 2012.pdf

[35] Pecoraro A, Mimiaga M, C O'Cleirigh SS. Depression, substance use, viral load, and CD4+count among patients who continued or left antiretroviral therapy for HIV in st. Petersburg, Russian Federation. AIDS Care 2015.

[36] Taniguchi T, Shacham E, Onen NF, Grubb JR, Overton ET. Depression severity is associated with increased risk behaviors and decreased CD4 cell counts. AIDS Care 2014; 26(8): 1004-12. [http://dx.doi.org/10.1080/09540121.2014.880399] [PMID: 24479743]

37] Berhe H, Sciences H. PREVALENCE OF DEPRESSION AND ASSOCIATED FACTORS AMONG PEOPLE LIVING WITH HIV/AIDS IN TIGRAY, NORTH ETHIOPIA: A CROSS SECTIONAL HOSPITAL BASED STUDY. Int J Pharm Sci Res 2013; 4(2): 765-75

[38] Tebikew Yeneabat AB, Amare T. Factors associated with depressive symptoms in people living with HIV attending antiretroviral clinic at Fitche Zonal Hospital, Central Ethiopia: cross-sectional study conducted in 2012. Dovepress 2017; pp. 2125-31.

[39] Stewart RC, Umar E, Tomenson B, Creed F. A cross-sectional study of antenatal depression and associated factors in Malawi. Arch Women Ment Health 2014; 17(2): 145-54.

[http://dx.doi.org/10.1007/s00737-013-0387-2] [PMID: 24240635]

[40] Seth P, Kidder D, Pals S, et al. Psychosocial functioning and depressive symptoms among HIV-positive persons receiving care and treatment in Kenya, Namibia, and Tanzania. Prev Sci 2014; 15(3): 318-28.

[http://dx.doi.org/10.1007/s11121-013-0420-8] [PMID: 23868419]

[41] Brittain K, Mellins CA, Phillips T, Zerbe A. Social Support, Stigma and Antenatal Depression Among HIV-Infected Pregnant Women in South Africa. AIDS Behav 2016.

[PMID: 27052843]

[42] Logie C, James L, Tharao W, Loutfy M. Associations between HIVrelated stigma, racial discrimination, gender discrimination, and depression among HIV-positive African, Caribbean, and Black women in Ontario, Canada. AIDS Patient Care STDS 2013; 27(2): 114-22.http://www.ncbi.nlm.nih.gov/pubmed/23373665 [http://dx.doi.org/10.1089/apc.2012.0296] [PMID: 23373665]

[43] Benoit AC, Light L, Burchell AN, et al. OHTN Cohort Study Team; Ontario CHIWOS Research Team. Demographic and clinical factors correlating with high levels of psychological distress in HIV-positive women living in Ontario, Canada. AIDS Care 2014; 26(6): 694-701. [http://dx.doi.org/10.1080/09540121.2013.855301] [PMID: 24215281]

[44] Gonzalez A, Zvolensky MJ, Parent J, Grover KW, Hickey M. HIV symptom distress and anxiety sensitivity in relation to panic, social anxiety, and depression symptoms among HIV-positive adults. AIDS $\begin{array}{llll}\text { Patient Care } & \text { STDS 2012; } & \text {; }\end{array}$ 156-64.http://online.liebertpub.com/doi/abs/10.1089/apc.2011.0309 [http://dx.doi.org/10.1089/apc.2011.0309] [PMID: 22248334]

\section{(C) 2020 Yousuf et al.}

This is an open access article distributed under the terms of the Creative Commons Attribution 4.0 International Public License (CC-BY 4.0), a copy of which is available at: https://creativecommons.org/licenses/by/4.0/legalcode. This license permits unrestricted use, distribution, and reproduction in any medium, provided the original author and source are credited. 